Abstracta Iranica Iranica

Revue bibliographique pour le domaine irano-aryen

Volume 28 | 2007

Comptes rendus des publications de 2005

\title{
Zendegī va še'r-e Ṭāleb-e Āmolī, šā'er-e gol-hā-ye ātaš. Tehrān, Entešārāt-e Zavvār, 1383/2004, 414 p.
}

\section{Franklin Lewis}

\section{(2) OpenEdition}

1 Journals

\section{Édition électronique}

URL : http://journals.openedition.org/abstractairanica/21051

DOI : 10.4000/abstractairanica.21051

ISSN : 1961-960X

Éditeur :

CNRS (UMR 7528 Mondes iraniens et indiens), Éditions de l'IFRI

\section{Édition imprimée}

Date de publication : 15 mai 2007

ISSN : 0240-8910

\section{Référence électronique}

Franklin Lewis, « Zendegī va še'r-e Tāaleb-e Āmolī, šā'er-e gol-hā-ye ātaš. Tehrān, Entešārāt-e Zavvār, 1383/2004, 414 p. », Abstracta Iranica [En ligne], Volume 28 | 2007, document 349, mis en ligne le 18 septembre 2007, consulté le 25 septembre 2020. URL : http://journals.openedition.org/ abstractairanica/21051 ; DOI : https://doi.org/10.4000/abstractairanica.21051

Ce document a été généré automatiquement le 25 septembre 2020.

Tous droits réservés 
Zendegī va še'r-e Ṭāleb-e Āmolī, šā'er-e gol-hā-ye ātaš. Tehrān, Entešārāt-e Zavvār, 1383/2004, 414

p.

Franklin Lewis 
1 The author, who hails from Āmol like Țāleb, became an amateur aficionado of the poet during his college days, after his father suggested that he explore whether their 16th century fellow townsman's literary reputation was fully justified. Qanbari dedicates the work to his father and his high school teachers (10), while recognizing that the work is more a young man's testament of appreciation than a polished scholarly work (8). The introduction is cognizant of what literary histories (e.g., Rypka, Browne) say about Tâaleb-e Āmolī, but does not quite manage to escape from the format of the tadkere. The introduction to the poet tells us about Āmol and its legendary founding, Țāleb's family, and it attempts to extract physical information about the poet from the obviously highly conventional imagery of his gazals, e.g., the gazal with radif "az bas ke da'iff-am" is submitted (pp. 29-30) as evidence for the poet's emaciation and physical torpor, a rather dubious premise given the common topos of emaciation, even if we do find some genuine biographical circumstances in Ṭāleb's verse, e.g., his use of opium (pp. 34-5).

2 The bulk of the book is a culling of some ten percent of the ghazals of Țāleb, each given a title from a phrase appearing within the poem. The author admits that his selection of gazals (from the error-riddled edition of the Kolliyāt-e divañn-e ašār-e Țāleb prepared by Seyyed Moḥammad Țāherī Šahāb, acquired in his youth) represents the not-yetmature esthetics of his youth, but these poems are produced in a readable layout, correcting the printing mistakes of the Divann, with an index of first lines and another of proper names. For a more scholarly work, the author himself refers us to Farāmarz Gūdarzī, Zendegī-nāme va kār-nāme-ye adabi-ye Ṭāleb-e Āmolī (Vezārat-e farhang va eršāde eslāmī, 1382/2003), which appeared too late for Qanbarī to incorporate into the results of the present book.

\section{INDEX}

Thèmes : 11.1.1. Littérature persane classique

\section{AUTEURS}

\section{FRANKLIN LEWIS}

University of Chicago 